\title{
Moral Curiosity Cabinets: Listing and the Character Sketch in Addison and Steele's Periodicals
}

\author{
Theresa Schön
}

An essentially collaborative project undertaken by Joseph Addison and Richard Steele, the Tatler (1709-1711) and the subsequent Spectator (1711-1712/1714), capture the authors' efforts to establish and communicate a set of moral norms as the basis of what they designed to be a fundamentally polite society. Observing a careful balance of entertainment and instruction, Addison and Steele implemented their wide-ranging moralistic program with the help of their personae Isaac Bickerstaff, Esq. (Tatler) and Mr. Spectator (Spectator), whom they sent out to observe and describe the manners and morals of fictionalized contemporary London society.

In addition to the very explicit moralizing of their personae, Addison and Steele's method of choice was the Theophrastan character sketch, a genre of high popularity in seventeenth-century England. Easily lending

\section{T. Schön $(\bowtie)$}

Interdisciplinary Centre for European Enlightenment Studies (IZEA) of Martin Luther University Halle-Wittenberg, Halle, Germany

(C) The Author(s) 2022

R. A. Barton et al. (eds.), Forms of List-Making: Epistemic, Literary, and Visual Enumeration, https://doi.org/10.1007/978-3-030-76970-3_4 
itself to satire, a character sketch represents an ethical, social, moral type of man or woman, commending (or exposing) behavioral norms to the reader and, thus, providing orientation in an increasingly complex world (Hockenjos 2006, 35-85). Traditionally plotless, the usually fairly short verse or prose sketches simply enumerate-vertically or horizontally-typical examples of the type's (linguistic) behavior, outward appearance, and sometimes short anecdotes (Smeed 1985, 276-284). Each sentence underlines the type's nature, often anaphorically adding ("He ... He ...") yet another detail to the picture as it develops over course of the sketch, thus creating coherence among seemingly disparate instances. Usually published in so-called character books, the collections present the sketches in no apparent order; they are a more or less random list of characters without a narrative frame. ${ }^{1}$

Addison and Steele's character sketches differ broadly from traditional Theophrastan examples. Expanding the anecdotal element found in earlier material and embracing the first-person perspective as well as the circumstantial style of their French predecessor Jean de la Bruyère, ${ }^{2}$ they used a fundamentally empirical approach and chose to represent their moral types in interaction. Shown in concrete (fictionalized) situations, in public and private, in fictionalized contemporary London, individualized and endowed with personal (and usually telling) names, the types meet and converse with the personae as well as the numerous other types of men and women populating the periodicals. Yet, while the majority of their sketches are characterized by a strong narrative element, the periodicals also experiment with the genre's essential affinity to enumeration and feature a small group of texts in the form of lists. ${ }^{3}$ In contrast to Theophrastan character sketches, however, in which each item or sentence in the text more or less straightforwardly confirms the nature of the type, the epistemological process in Addison and Steele's examples is more complex. They combine the character sketch with contemporary non-literary forms of notation (last will and testament, inventory, genealogy, library cata$\log ) .^{4}$ In order to understand the texts (adequately), the readers need to be familiar with the methodological specificities and the socio-cultural implications of these forms. Although the texts ultimately serve a moralistic purpose in exposing moral excess, the forms Addison and Steele adapted in these cases carry different affordances that inform the readers' response and affect the epistemological dimension of these texts: the form of the text defamiliarizes the (more or less well-known) content (i.e., the moral types), which readers may have known from their reading or the 
theater. The list decelerates the reading process, heightens the readers' attention, and encourages them to pause; in turn, this pause prompts readers to reflect on the knowledge the list communicates as well as on the manner in which this moral knowledge relates to their experience of the world.

In the following pages, I will examine two such lists from the Tatler and the Spectator in detail: the will and testament of the Virtuoso Nicholas Gimcrack (Tatler no. 216) and the library catalog of the Romance Heroine Leonora (Spectator no. 37) - two forms intimately related to the practice of collecting. Briefly considering the traditions the texts relate to, I shall trace the mechanisms of the epistemological process for each text individually before considering them comparatively in their position in the periodicals' collection more generally. The capacity of these texts as character sketches and their place in the periodical project endow them with an additional quasi-scientifick, ${ }^{5}$ quasi-sociological function: The texts list naturalist and bibliophile curiosities; at the same time, these lists (and the moral types captured by these lists) emerge as collectibles themselves, as curiosities gathered by Bickerstaff and Mr. Spectator to become part their moral curiosity cabinets.

\section{The Will of a Virtuoso (Tatler No. 216)}

Testaments represent the testators' attempt of reaching out from beyond their death to the living. They endow a voice to one who is no longer able to speak. Hence, the testament, as Ulrike Vedder has explained, is a medium of return from death to life, of transition from life to death, and of transfer of the testator's legacy to the heirs $(2011,23)$. In this function, the testaments (and testators) continue to interfere with their family's affairs and society more generally. In particular, the legacies may determine the heirs' future lives, being a symptom or even a cause of social, legal, and cultural conflict (Vedder 2011, 24). A functional text used by social representatives from the husbandman to the king, the testament is, as Ulrich Bach explains, characterized by a dual purpose relating to a person's earthly, material existence on the one hand-that is, the legal document regulating the bequeathal of property from the dying testator to the heirs - and to the testator's religious fate on the other-that is, the relationship to God and the salvation of the soul (Bach 1977, 39/41). This dual purpose entails a tension between the plain (and formulaic) language and ordinary content of the document, laying out the details regarding 
the testator's property, and its "high" purpose, its function as religious instrument and legal record (Bach 1977, 41). Endowed with an important epistemic dimension, the testament reflects on the testator as well as the relationship between testator and heirs. The epistemic quality relies on the symbolic force of the individual legacies, which assume the role of tertium comparationis. In its capacity as an object deemed important enough to explicitly figure as a legacy, the object sheds light on the character (and the identity) of the testator and-depending on the (un-)suitability of the match (legacy/heir) — on the character of the heir.

The example in The Tatler is clearly indebted to the tradition of the mock testament, which goes back to antiquity, and its comic-satiric parodies often taking the form of beast testaments, and attests to the appeal of mocking sublime forms. According to Bach (1977, 77-80), mock testaments build on the testament's function of revealing the speaker's nature, thus enabling the satirical denunciation of the speaker/author and/or the heirs. Relying on the moral weight of last words, they use the legacies' closed range of items to criticize particular social or political groups, moral flaws, and particular circumstances. Their critical impetus reveals the affinity of the testator to the fool: like the fool, the testator has the freedom of mocking others without punishment, as the testament is only opened after death (Vedder 2011, 50). A particularity of mock testaments is linked to the conventional and fairly rigid form of last wills-a three-part structure with opening formulae, legacies, and closing formulae (Vedder 2011, 50); so, the form quintessentially participates in creating meaning beyond the particular content of the testament (Bach 1977, 48). As the document represents the authority of the church, the respective jurisdiction, and so forth, the approach of the satirist at least partly touches the authorities themselves by playing with the conventional form.

The Tatler's issue no. 216 reprints the will of Nicholas Gimcrack, the eponymous Virtuoso of Thomas Shadwell's Restoration comedy (1676). ${ }^{6}$ The issue primes the reader for the will adequately by providing an inset generic character sketch of the type of the Virtuoso, that underlines the type's nonsensical obsession with trivialities, with "mean and disproportioned Objects," with "the Refuse of Nature" (Bond 1987, vol. 3, 132-133), and thus emphasizes the ideal of temperance and modesty. ${ }^{7}$ The introductory passage explicitly refers to the type's inclination to collecting, "hoarding up in their Chests and Cabinets such Creatures as others industriously avoid the Sight of" (Bond 1987, 133). Tracing back to the Renaissance, collecting as an end in itself, driven by a particular 
propensity and performed with some manner of expertise, often at the cost of social duties, as it is suggested here, mirrors the collector's fear of the contingency of the world, a pleasure comparable to that of the hunter as well as a disposition toward order and ostentation (Stagl 1998, 41-45). ${ }^{8}$ The collector compiles a collection, a form of materialized memory, a structured entity of previously unconnected parts which are then related in a meaningful way and, thus, represent that section of the world from which they have been taken (Stagl 1998, 41). As a means to capture such a collection in writing, the list graphically mirrors this process, allows the collectors to communicate with their peers even in their absence, and provides the grounds for the (listed) collection to be removed from its original setting (the collector's cabinet) to new and different contexts such as a satirical paper, thus enabling discursive mobility.

The testament's form follows the traditional structure (see Bach 1977, 36-37) and is immediately recognizable by its formulaic beginning (and conclusion): "I Nicholas Gimcrack being in sound Health of Mind, but in great Weakness of Body, do by this my last Will and Testament bestow my Worldly Goods and Chattels in Manners following: [...]" (Bond 1987, vol. 3,133 , emphasis added). The text's standard reference to the testator's "sound Health of Mind" satirically exposes Gimcrack. Though no clear indication of madness, the testator's beliefs and behavior as suggested by the following list strongly contrast with the concept of a "sound mind" and appear to lie beyond the confines of reason. Gimcrack's reference to his "Worldly Goods and Chattels" anticipates a significant void in his will: Gimcrack devotes his text exclusively to the management of his worldly, ephemeral affairs and ignores the other core ideas traditionally found in testaments, namely, soul, body, and sins (Bach 1977, 82).9 Gimcrack's disregard for the fate of his soul suggests that he has lost sight of, or is indifferent to, the concept and meaning of salvation and eternal happiness.

In characteristic parallel sequencing (Bach 1977, 37), the following list allots individual items to the heirs.

Imprimis, To my dear Wife,

One Box of Butterflies,

One Drawer of Shells,

A Female Skeleton,

A dried Cockatrice.

Item, To my Daughter Elizabeth,

My Receipt for preserving dead Caterpillars: 
As also my Preparations of Winter May-Dew, and Embrio Pickle.

Item, To my little Daughter Fanny,

Three Crocodile's Eggs.

And upon the Birth of her First Child, if she marries with her Mother's Consent,

The Nest of an Humming Bird.

(Bond 1987, vol. 3, 133-134, emphasis in original)

The text takes up the standard combination of legacy and heir. Appearing in a very condensed form, Gimcrack's will refrains from more elaborate and possibly affectionate explanations and largely presents a vertical enumeration of items (per heir). ${ }^{10}$ The text only breaks with this pattern toward the conclusion of the testament, where Gimcrack sets down the legacies to his son Charles. Whereas the previous entries singled out individual items, this passage contains the remainder of his possessions, merely presented as unspecified (and, by implication, unordered) accumulation, that is, "all my Flowers, Plants, Minerals, Mosses, Shells, Pebbles, Fossils, Beetles, Butterflies, Caterpillars, Grashoppers, and Vermin, not above specified: As also all my Monsters, both wet and dry" (Bond 1987, vol. 3, 135). While, of course, allowing the periodical's editors to adhere to the spatial limitations of the folio half-sheet, the text thus presents the individual items in "the Apartment of a Virtuoso," in his "Chests and Cabinets" (Bond 1987, 132-133) in a visually easily accessible format. The nature of the items is, indeed, telling in several ways. Gimcrack exclusively passes on items related to the natural sciences, collectibles associated with contemporary curiosity cabinets, that apparently constitute his estate. The items on the list are of a domestic - for example, butterflies, grasshoppers, mosses, pebbles - and foreign origin—for example, the "Crocodile's Eggs" and the "Nest of an Humming Bird" cited above, or "The Mummy of an Egyptian King" and the "Horned Scarabaeus" (Bond 1987, 134), pointing to the extensive travels natural historians undertook, to the scientifick excursions to parts of the earth as yet unknown, and to the exploration of the minute and invisible. Some legacies suggest methodological knowledge developed by and necessary to contemporary naturalists (e.g., Gimcrack's "Receipt for preserving dead Caterpillars," Bond 1987, 134). Most of the items represent rarities of an exotic, if not monstrous nature and are, hence, of a high scientifick (and possibly also monetary) value. In some instances, the scientifick value clashes with contemporary notions of propriety, an aspect that the form of the testament emphasizes by linking 
individual testators with certain items: Considering, for instance, that corpses (e.g., for scientifick purposes such as anatomical dissections) could not be acquired legally and usually belonged to criminals, Gimcrack's legacy of a "Female Skeleton" to his wife clearly distances him from the periodical's moral standards. Indeed, the list builds toward a climax, moving from the "Female Skeleton" via "[m]y Rat's Testicles and Whale's Pizzle," Gimcrack's legacy to his fellow Virtuoso "Dr. Johannes Elscrickius” (Bond 1987, 134), to Gimcrack's deceased daughter “whom I keep by me in Spirits of Wine" and who represents but one example of his "Monsters, both wet and dry" that he gives to his second son Charles. As evidence of the owner's choices and values, the nature of the objects is clearly designed to suggest Gimcrack's monstrous morals.

This reading is confirmed and consolidated by the symbolic dimension of the items in Gimcrack's testament. For instance, the first three items that he bequeaths to his wife (see block quotation above) have a broadly positive connotation, entailing ideas of metamorphosis (butterflies), of Christ (shells), and memento mori (skeleton), the first two of which highlight the collector's habit of ordering ("Box," "Drawer"). The fourth legacy, the "Dried Cockatrice," however, is associated with superstition (cockatrice as basilisk, see $O E D$ ) as well as pride, envy, and slander (see Butzer and Jacob 2012, 230-231). The emblematic meaning of the items largely relies on the literary-cultural tradition and, particularly, on specific knowledge of the Bible. ${ }^{11}$ The text suggests that Gimcrack is unaware of his legacies' symbolic dimension, an aspect which is betrayed by the list and its arrangement as well as by the context of its publication: While the individual item in the collection assumes its meaning as collectible by being part of the collection, a meaning which is relevant, primarily, to other collectors, the testament, and particularly its publication in a satirical periodical, relocates the item to a different context (law, religion, society), in which the item's socio-religious connotation moves center stage. This mechanism further gains momentum by the text's coupling of the items with the respective heirs. The list thus reveals his unawareness or, even worse, his ignorance that surely results, the text implies, from his exclusive focus on "the Refuse of Nature" (Bond 1987, vol. 3, 134). At the same time, the items' symbolic meaning-in true mock testament fashionreflects on the heirs, who are publicly exposed through Gimcrack's cultural illiteracy.

As the most important worldly purpose of a gentleman's testament is to provide economically for his surviving relatives, Gimcrack's heritage 
appears to confirm Bickerstaff's earlier criticism: Gimcrack's preoccupation with nature has disconnected him "from the Knowledge of the World" (Bond 1987, 132). The legacies he bestows on his wife, that is, her dower on which she was to subsist for the remainder of her life, are scientifick collectibles whose (monetary) value, if any, may well be unknown to the non-naturalist. The widow's lack of expertise might, in turn, entail the loss of the object - she may simply give it away or throw it out-and, hence, the loss of money and subsistence. ${ }^{12}$ What is more, the testament's distribution of wealth deviates from the prevalent contemporary social and moral norms. Gimcrack, it appears, allots his legacies according to naturalist interests, not according to family or legal tradition. His wife's dower strongly contrasts with the legacies Gimcrack bequeaths to his "learned and worthy Friend Dr. Johannes Elscrickius" (Bond 1987, 134, emphasis in original), namely, his "Rat's Testicles, and / Whale's Pizzle" (Bond 1987, 134). Taking rarity as the crucial contemporary criterion for a curiosity to sell well, for example, at auctions (Cowan 2005, 135), Gimcrack's testament clearly favors his fellow Virtuoso over his wife: the scientifick network, whose international scope is emphasized by Elscrickius' Germanic name, undermines the traditional social network, that is, the family (Daston 2011, 102-103; Stagl 1998, 49-51). ${ }^{13}$

Gimcrack's testament thus unsettles the social hierarchy and the social structure. It can be seen as a symptom of existing and the cause of further social conflict. This conclusion is confirmed by the explanation Gimcrack provides for disinheriting his eldest son John, thus violating the laws of primogeniture. As Gimcrack's commentary reveals, his decision is again based on scientifick loyalty, rather than filial/family duty:

My eldest Son John having spoken disrespectfully of his little Sister whom I keep by me in Spirits of Wine, and in many other Instances behaved himself undutifully towards me, I do disinherit and wholly cut off from any Part of this my Personal Estate, by giving him a Single Cockle Shell. (Bond 1987, vol. 3, 134-135)

In this passage, Gimcrack's implicit auto-characterization serves as confirmation of his monstrous morals. He ranges his daughter's fetus, conserved in alcohol and surely resulting from a miscarriage, before his breathing son, thereby demonstrating his preference for death over life. More than that, the list prior to this passage, which evidently represents its moral climax, indicates that his emotional relationship to the fetus results from 
scientifick interest rather than a close familial bond. The text achieves this effect fundamentally by means of its formal shape. The list defamiliarizes the well-known content. The fact that the Virtuoso is wholly taken up by his study of odd (natural) objects and consequently estranged from his family was a common reproach at least since Shadwell's comedy. The Tatler condenses this knowledge into the connection between item and heir. Although the text does provide an explanatory narrative frame that helps to situate the testament, it is the reader's task to decipher the sociomoral meaning of the item/heir relation.

\section{A Lady's Library Catalog (Spectator No. 37)}

Akin in kind to the inventory, the library catalog has an important administrative function, keeping track of the publications and manuscripts available and simultaneously facilitating the retrieval of single (or several) volumes (Rösch 2012, 97-100). It assigns a place to each item and thus creates a spatial as well as an ideological order. The order of the items can be chronological, alphabetical, or thematic; it can be guided by the volumes' size (folio, quarto, octavo, etc.; see Jacobs 1999) or by genre. Depending on the order that is chosen, the catalog (and library) suspends temporality by bringing different periods together, setting them next to each other, thereby suggesting (or encouraging reflection on) the kinship of the items placed on the shelves (and on paper). As library space is so (over)loaded with (visual) information as to potentially overwhelm the viewer, the catalog serves as orientation-as a map-guiding the reader from the written/printed word(s) to the medium of the book (Krajewski $2012,82-83$ ). The creation of a catalog requires skill and education. In addition to being literate, the author needs literary, philosophical, and scientifick knowledge, as well as taste and judgment. Like the testament, the catalog reflects on the identity of the books' owner: the choice of books to be stored in the library and listed in the catalog mirrors the owner's values, preferences, and interests. In its educational (and economic) function, the catalog becomes an essential tool for shaping and storing the cultural capital necessary for social progress and, more particularly and very much in the spirit of The Spectator's historical context, for enlightenment.

The catalog of books in Spectator no. 37 has an anecdotal frame introducing the central character constellation that provides the occasion for Mr. Spectator's ensuing observations: one of the Spectator Club 
members, Sir Roger de Coverly, ${ }^{14}$ asks Mr. Spectator to deliver an important letter to an acquaintance of his, "Leonora," as she is christened by Mr. Spectator. The observations themselves can be divided into three parts: Mr. Spectator first devotes some time to describing the "Lady's Library" (Bond 1965, vol. 1, 153) as a physical space, that is, the room and its organization, before he provides the catalog of books and finishes the issue with a description of Leonora's character (her marital and social situation, her current passion, her country seat).

Mr. Spectator's approach to Leonora's library seems to be designed to arouse the reader's interest in what follows. In accordance with what Lorraine Daston has found to be the contemporary "psychology of natural philosophical inquiry" (Daston and Park 2001, 305), Mr. Spectator expresses his wonder at being invited "to walk into [the] Lady's Library" which, in turn, sparks his "great Curiosity" (Bond 1965, vol. 1, 153) and heightens his attention. Although his description of the room does not correspond to a (clear-cut) list, his text does mirror an enumerative and what appears to be a quasi-scientifick, systematic approach: he followsor, rather, his eyes follow-the organization of the books on the shelves, arranged "in a very beautiful Order" (Bond 1965, 153), from the Folios via the Quartos to the Octavos, each separated by a corresponding combination of China. Together with the remaining decorations adorning the room-including "one of the prettiest Grotesque Works that ever I saw, and made up of Scaramouches, Lions, Monkies, Mandarines, Trees, Shells, and a thousand other odd Figures in China Ware"-the interior design of the library (as physical space) prepares Mr. Spectator's reading of and judgment on Leonora's books (as captured by his catalog) and, ultimately, her character: "I [...] did not know at first whether I should fancy my self $[$ sic] in a Grotto, or in a Library" (Bond 1965, 154). Leonora shares with the Virtuoso a fascination for strange, exotic objects, which, in her case, have a different origin and serve a different function.

The catalog of books is explicitly marked as a selection, an extract from the books on the shelves and the list Mr. Spectator notes down: "Among several that I examin'd, I very well remember these that follow. [...] I was taking a Catalogue in my Pocket-Book of these, and several other Authors, when Leonora entred [sic]" (Bond 1965, 154/157, emphasis in original). Hence, it is very much Mr. Spectator's perspective and choice-first, in situ at Leonora's library and, second, later when preparing the issue-that determines the nature, shape, and function of the list created by $\mathrm{Mr}$. 
Spectator so as to represent Leonora's character. It contains 33 works in vertical format and in no apparent order, for example:

Ogleby's Virgil.

Dryden's Juvenal.

Cassandra.

Cleopatra.

Astrea.

Sir Isaac Newton's Works.

The Grand Cyrus: With a Pin stuck in one of the middle Leaves. (Bond 1965, vol. 1, 154, emphasis in original)

The works include titles of literary, philosophical, moralistic, and political works of modern and ancient origin. Contrary to a (professional) library catalog, Mr. Spectator's list presupposes a well-read reader. Most of the entries feature shortened titles, for example, "Sherlock upon Death" (Bond 1965, 155) for William Sherlock's A Practical Discourse Concerning Death, also reflecting on the bestselling nature of the works; the majority of the entries drop the authors' names (particularly for the literary works, the classics sometimes including translators), and lack any reference to the place or date of publication.

Very much like Gimcrack's legacies, Leonora's collection of books metonymically mirrors her character. The titles on the list can be divided into seven (thematic) categories: romance/literature, natural philosophy/ learning, morality - as the largest groups - as well as education, courtship, and politics/current affairs. Thus, at first sight, Leonora's library suggests a broad interest in various fields of socio-cultural (learned) activity. Yet, Mr. Spectator's initial proviso and his later observations qualify this reading. He introduces the catalog claiming:

Upon my looking into the Books, I found there were some few which the Lady had bought for her own use, but that most of them had been got together, either because she had heard them praised, or because she had seen the Authors of them. (Bond 1965, vol. 1, 154)

With this qualification, Mr. Spectator insinuates Leonora's failure of actively engaging with the majority of the books on her shelves, which she possesses, one might infer, in order to appear, rather than to be learned. ${ }^{15}$ Among the selection that Mr. Spectator represents in his paper, only five of the works bear traces of Leonora's engagement with them: Mr. Spectator 
finds Leonora's copy of Madeleine de Scudéry's Artamène or the Grand Cyrus "with a Pin stuck in one of the middle Leaves" (Bond 1965, 154), John Locke's Essay Concerning Human Understanding "With a Paper of Patches in it" (Bond 1965, 155), Thomas D'Urfey's Tales Tragical and Comical "Bound in Red Leather, gilt on the Back, and doubled down in several places", Leonora's copy of Madeleine de Scudéry's Clelia "Which opened of it self $[$ sic $]$ in the Place that describes two Lovers in a Bower", and "A Prayer Book: With a Bottle of Hungary Water by the side of it" (Bond 1965, 156). The markings and signs of wear mirror the reading process and, by implication, provide insight into the intellectual priorities of the reader. Surely, the text implies, the books that bear such traces are those most often and most earnestly read. The material evidence Mr. Spectator finds on the shelves reveals that Leonora prefers romance, a literary genre commonly related to the female reader. Hence, Mr. Spectator uses an empiricist framework-(attentive) observation and note taking (Daston 2011) — as a means to authenticate his claim on Leonora's character: she emerges as a romance heroine.

This reading is confirmed by the remainder of the issue in which Mr. Spectator unveils the relationship between Leonora's reading and her perspective on the world to the reader. In a truly inductive manner, he observes that the books she reads have an effect on her character: "As her Reading has lain very much among Romances, it has given her a very particular Turn of Thinking, and discovers it self [ sic] even in her House, her Gardens and her Furniture" (Bond 1965, vol. 1, 158). Sir Roger's description of Leonora's country estate that "looks like a little Enchanted Palace [... with] Artificial Grottoes [...], shady Walks, [...] Bowers, and [...] Cages of Turtles" (Bond 1965, 158) serves as final evidence. A crucial part of his observational method, Mr. Spectator uses the list as a mnemonic device, allowing him to graphically represent his perceptions and to store them for future reflections. ${ }^{16}$

All in all, Mr. Spectator reconstructs his visit to Leonora chronologically, moving from his observations of the spatial to the bibliographical particularities of her library, completing his findings (and hypothesis) with further evidence provided by Sir Roger. Within this structure, the catalog provides him with a means to account for and, importantly, alert the reader to the cause of Leonora's strange taste and nature. Her particular biographical situation as widowed and childless woman (see Bond 1965, 157-158)—thus being, Mr. Spectator suggests, without a purposeallows her to devote her time to her library. It is her choice of reading, her 
preference for publications that are "of little more use than to divert the Imagination" as opposed to "Books as have a tendency to enlighten the Understanding" (Bond 1965, 158), that turned her into a Romance Heroine-a conclusion confirmed by her library (in its double sense). Mr. Spectator opposes Leonora's want of judgment with his own skill in choosing adequate- "enlighten[ing]"-reading for her (and other women). Faced with the multitude of impressions assembled in the library (furniture, accessories, books), he extracts those that allow him to arrive at an understanding of the owner's motivation and character. At the same time, his catalog becomes a source of social power, determining in prescriptive manner the proper reading material for his female readers.

\section{Conclusion}

In sum, the two lists share a number of characteristics. Both testament and library catalog list the possessions of a type. The possessions metonymically reveal the character of the owner, suggesting past choices and prevalent values, thus being indicative of the owner's identity. While all testaments and library catalogs certainly indicate the preferences of their owner, in this case, the symbolic dimension of the items (and lists) is emphasized by being printed in Addison and Steele's periodicals. The periodicals' self-proclaimed intention of reforming society as well as the texts' frame in the individual issues explicitly encourages the reader to read between the lines. Both lists have a vertical structure and are empirically closed, that is, ontologically limited by what is available to the senses. What is more, both propose selections from a larger group of items. The magnitude and shape of the catalog is determined by Mr. Spectator's memory (assisted by his notes); so, the catalog essentially mirrors his choice. By contrast, the testament, an ego-document, is governed by Gimcrack's choice: he decides which items to accentuate among his stock of belongings, thus making the testament an instance of deliberate selffashioning. Both lists represent emphatically written forms, guiding the reader from the printed word to the material object. In the case of the catalog, the written form has a double reference: first, to Mr. Spectator's notes in his "Pocket-Book" (Bond 1965, vol. 1, 157) and, second, to the published catalog in the Spectator issue. While Gimcrack's testament follows the culturally established format, it lacks any of the conventional religious references - an element that is, of course, telling and relates to the mainstream moralistic criticism of contemporary naturalists allegedly 
neglecting their religious duties for their obsessive preoccupation with nature. The implication is that Gimcrack thus jeopardizes his afterlife. ${ }^{17}$ Furthermore, the two lists relate in similar ways to class and gender. Both forms are associated with the propertied, endowed, at least in some manner, with enough leisure time for collecting and for reading as well as pursuing naturalist inquiries. Both texts (or types) clash with gender norms. For Gimcrack, this clash is primarily relational: he ignores his social duties as patriarch and even interrupts the established social order. The catalog adds another element. At the time, the library was still perceived as a space of "retreat and solitude" (Williams 2017, 50), as Mr. Spectator's surprise at being invited to enter the "Lady's Library" suggests (Bond 1965, vol. 1, 153). By contrast, Leonora has, as Mr. Spectator finds, turned this allegedly intimate and private space into a "place for public display" (Williams 2017, 50), ultimately defeating the library's purpose, namely self-reflection and learning or, as Mr. Spectator puts it, "enlightenment."

Although the lists are both tailored to the same purpose, that is, capturing the nature of a socio-moral type of man and woman, the way they operate reveals fundamental differences. Gimcrack implicitly characterizes himself by explicitly rating the items and relationships. ${ }^{18}$ Furthermore, the testament is an official document extending, in some manner, into the public sphere. Gimcrack thus explicitly sets up a grid that exposes his moral disposition. At first glance, the procedure of rating the individual objects according to value appears to be similar to the weight individual books receive in Leonora's library, worn by use. However, Leonora's reading leaves involuntary traces (e.g., in the case of the book that opens by itself in one place), not necessarily meant for others to see. Her library represents a private space, voluntarily disclosed to Mr. Spectator who then makes it public in his enumerative description and catalog. Hence, the lists are additionally differentiated by agency: Gimcrack exposes himself, while it is Mr. Spectator's observational skills and interpretive glance that make Leonora's character accessible to the reader. The form of the testament, and Gimcrack's testament in particular, creates a hierarchy between individual items in his collection by singling out legacies and by allotting them to respective heirs. ${ }^{19}$ The result is a hierarchy of scientifick (and, possibly, monetary) value. The catalog, by contrast, levels hierarchy by listing books in no apparent order; each book, the catalog implies, has the same cultural value. In order to effectively capture Leonora's character, Mr. Spectator's list undermines this equalizing function of the catalog in some 
measure; the signs of wear create the hierarchical structure of the type's reading. The catalog as a whole, however, contains books of different moral value (high value of philosophy/morality versus low value of romance); it is in their blend that they achieve a balance of moral (and cultural) value. Furthermore, the issues in which the lists are published differ with regard to their epistemological procedure. The Tatler issue proposes a deductive framework, leading from a generic, abstract definition of the type (Bond 1987, vol. 3, 132-133) to a representative example located in space and time, Gimcrack's will. The Spectator issue, by contrast, works inductively with Mr. Spectator as a representative observer showing the reader how to come to terms with what he sees. In this context, Mr. Spectator uses the catalog to provide evidence for his reading, that is, for his hypothesis of Leonora's character.

Ultimately, both lists mirror the activity of collecting: natural and cultural curiosities in Gimcrack's testament and books in Leonora's case. Their incorporation into the periodicals - a publication format intricately connected to the idea of listing and enumeration ${ }^{20}$ — transforms them into items in a collection, in a process that very much resembles the creation of the catalog in Spectator no. 37. As a result, the lists-and the socio-moral types captured by these lists-become collectibles themselves and are, in turn, incorporated in yet another list: the index in the collected editions. ${ }^{21}$ As much as testaments in literature always implicitly address the question of the literary archive and of cultural memory (Vedder 2011, 27), the two lists analyzed here serve to register in satirical fashion exaggerated behavioral patterns marked as typical of their time and, thus, as memorable. ${ }^{22}$ The types emerge as moral curiosities in the Tatler's and the Spectator's curiosity cabinets. Hence they are evidence of the authors" "hoarding up in their Chests and Cabinets such Creatures as others industriously avoid the Sight of" (Bond 1987, vol. 3, 133), a practice very much akin to the Virtuoso's activities, yet allegedly inspired and morally justified by their dedication to the "commonweal."

\section{Notes}

1. This design, together with the contemporary practice of ever-expanding editions, hints at the (technically) infinite nature of observation and, by implication, of character writing, with new observational details and new types simply added to a constantly increasing repertoire. An exception is 
Joseph Hall's early seventeenth-century character book, which arranges the types in two parts according to their predominant virtues and vices.

2. See Caractères ou les Mours de ce Siècle, which were published in eight continuously expanding editions in Paris from 1688.

3. With Eva von Contzen, I define the list as a formal unit consisting of distinct parts with a very loose, if any, link to the surrounding narrative (2017b, 222). The relationship between the components of the list is complex: As Robert Belknap argues, they "cohere to fulfil some function as a combined whole, and by discontinuity the individuality of each unit is maintained as a particular instance, [...]. Each unit in a list possesses an individual significance but also a specific meaning by virtue of its membership with the other units in the compilation [...]" $(2004,15)$. Depending on the way the list is contextualized, it may have a variety of affordances; crucially, it may provide or reflect identity or order, invite the reader to fill the gaps between its parts and tell a story, and have a range of different purposes-legal, religious, administrative, therapeutic, and, indeed, didactic (von Contzen 2017a, 322).

4. This methodological choice testifies to the contemporary significance of the list, a crucial instrument for naturalists in their attempts at systematically understanding and ordering nature for Bacon's Instauratio magna, which is reflected, for instance, in Robert Boyle's advice to naturalists to use "General heads of Inquiry" in their exploration and description of nature (Boyle 1665/1666, 186) or Patrick Blair's systematic description of the anatomy of an elephant including a tabular synopsis of the animal's skeleton (Blair 1710, 143). For a discussion of late seventeenth-century attempts at systematizing science, see Hunter 2007.

5. The archaic spelling of the term is meant to indicate the somewhat elaborate epithet "natural philosophical and natural historical," while emphasizing that the term "science" in its modern understanding only emerged in the mid-nineteenth century (see $O E D$ ).

6. While Addison and Steele take up Shadwell in Gimcrack's aversion to useful knowledge ("I seldom bring anything to use; 'tis not my way. Knowledge is my ultimate end" Shadwell 1966, 47), as the quintessential characteristic of their Virtuoso, their catalog of Gimcrack's possessions seems to be more indebted to Mary Astell's sketch of the Virtuoso in her Essay on the Defence of the Female Sex (1696) which refers not only to entomological artifacts (e.g., caterpillars), but also to specimens of a marine origin (e.g., "Shells and Pebbles of all Shores") and to the type's activity of conserving: "He preserves carefully those Creatures, which other Men industriously destroy, $[\ldots]$. He is the Embalmer of deceas'd Vermin, and dresses his Mummy with as much care, as the Ancient Egyptians did their 
Kings" (Astell 1696, 96-99). For an analysis of Astell's sketch of the type and its history more generally, see Houghton 1942.

7. As in most other characters, Bickerstaff attacks the imbalance in the Virtuoso and the type's neglect of the affairs of life that his exclusive focus on "trivialities” entails. Gimcrack's telling name confirms his nature.

8. In the type's affinity to collecting and the collector, the Virtuoso is linked to the Pedant, the Antiquary, and the Critic, broadly popular in seventeenthcentury character books. See Assmann 1998.

9. Thus, the text equally leaves the pattern of traditional mock testaments that typically made a legacy of the testator's sins (see Bach 1977, 81).

10. This conforms to the literary tradition of the mock testament, as Bach's examples illustrate (e.g., Bach 1977, 80-85), and contrasts with historical examples such as the naturalist Robert Boyle's testament (see Boyle 1772, clviii-clxxi).

11. At the same time, a familiarity with the tradition of the mock testament certainly promotes the reflection on the symbolic meaning of the legacies on the part of the reader.

12. He conceptualizes the "Nest of an Humming Bird" as a reward for his daughter Fanny's complying with her mother's wishes, thus for conduct that accords with her filial duties. The same applies to the recompense for his brother's support of his son. In this passage, he even equates installing someone into an estate ("Lands") with a "Collection of Grasshoppers" (Bond 1987, vol. 3, 134), supposedly level due to the sheer size of the collection.

13. Gimcrack emphasizes his bias toward his naturalist friends in his comment on his legacies to Elscrickius which he defines as "an eternal Monument of my Affection and Friendship for him" (Bond 1987, vol. 3, 134), the only extensive expression of emotion and, remarkably, the only reference to eternity and the afterlife in his will. The sexual connotation of the legacies hint at a homosexual relationship and, by extension, suggest a potential threat to the welfare and subsistence of society.

14. The Spectator Club allows the periodical's authors to expand their perspective on contemporary society by assembling a number of "experts." Each member represents a central social sphere: the country gentry (Sir Roger de Coverly), trade (Sir Andrew Freeport), the church/religion (the Clergyman), literary criticism (the Templar), and fashionable society (the Restoration Rake Will Honeycomb).

15. Through this detail, Leonora is associated with the type of the Book Pedant, personified in Tatler issue no. 158 as Tom Folio, who is more interested in the outside of the books he collects and their material quality than in their actual content (see Bond 1987, vol. 2, 384-387; and Assmann 1998, 271-272). 
16. In Spectator 46, Mr. Spectator provides another specimen of his notes (see Bond 1965, vol. 1, 195-199).

17. This connects with his legacy of the "Female Skeleton" which indicates Gimcrack's disregard of the commands of religious piety, disrespecting the body's right of eternal rest. While, of course, criminals forfeited such rights, the use of corpses for scientifick purposes was highly contested at the time, not least for religious reasons.

18. He elevates the legacy he bestows upon Johannes Elscrickius "as an eternal Monument of my Affection and Friendship" while he degrades the legacy to his eldest son, whom he deprives of his inheritance "by giving him a Single Cockle-Shell" (Bond 1965, vol. 1, 134-135).

19. For the link of enumeration and hierarchy, see Mainberger 2003, 7-8.

20. The individual issues are published consecutively in numerus currens format, technically an "infinite list," ultimately collected in bound editions (in close proximity or simultaneously to original publication) with an index.

21. The first collected editions were published during the papers' initial run and reissued in differing formats and by different editors throughout the eighteenth century and beyond. Collections also included (and include) selected editions (see, e.g., Erin Mackie's fairly recent Commerce of Everyday Life: Selections from The Tatler and The Spectator, Bedford/St. Martin's 1998).

22. The authors express a playful, yet acute awareness of posterity/future readers, especially in The Spectator (see Bond 1965, vol. 1, 422-426).

\section{REFERENCES}

Assmann, Aleida. 1998. Der Sammler als Pedant. In Sammler - Bibliophile Exzentriker, ed. Aleida Assmann, Monika Gomille, and Gabriele Rippl, 261-274. Tübingen: Narr.

Astell, Mary. 1696. An Essay in Defence of the Female Sex. London.

Bach, Ulrich. 1977. Das Testament als literarische Form: Versuch einer Gattungsbestimmung auf der Grundlage englischer Texte. Düsseldorf: Stern-Verlag.

Belknap, Robert E. 2004. The List: The Uses and Pleasures of Cataloguing. New York: Yale University Press.

Blair, Patrick. 1710. A Continuation of the Osteographia Elephantine: Or, a Description of the Bones of an Elephant, Which Died Near Dundee, April the 27th, 1706. In Philosophical Transactions 27 (327): 117-168. https://doi. org/10.1098/rstl.1710.0009.

Bond, Donald, ed. 1965. The Spectator. 5 vols. Oxford: Clarendon.

$\longrightarrow$, ed. 1987. The Tatler. 3 vols. Oxford: Clarendon. 
Boyle, Robert. 1665/1666. General Heads for a Natural History of a Countrey, Great or Small. In Philosophical Transactions (1665-1678), vol. I (1665-1666), 186-189.

Boyle, Robert. 1772. The Works of the Honourable Robert Boyle. Vol. 1. London.

Butzer, Günter, and Joachim Jacob, eds. 2012. Metzler Lexikon literarischer Symbole. Stuttgart: Metzler. https://doi.org/10.1007/978-3-476-05302-2.

Cowan, Brian. 2005. The Social Life of Coffee: The Emergence of the British Coffeehouse. New Haven: Yale University Press.

Daston, Lorraine. 2011. The Empire of Observation: 1600-1800. In Histories of Scientific Observation, ed. Lorraine Daston and Elizabeth Lunbeck, 81-113. Chicago: University of Chicago Press.

Daston, Lorraine, and Katharine Park. 2001. Wonders and the Order of Nature: 1150-1750. New York: Zone books.

Hockenjos, Katrin. 2006. Frauenbilder in englischen Charakterskizzen des 17. Jahrbunderts. Tübingen: Narr.

Houghton, Walter E. 1942. The English Virtuoso in the Seventeenth Century. Journal of the History of Ideas 3 (51-73): 190-219.

Hunter, Michael. 2007. Robert Boyle and the Early Royal Society: A Reciprocal Exchange in the Making of Baconian Science. The British Journal for the History of Science 40 (1): 1-23.

Jacobs, Edward H. 1999. Buying into Classes: The Practice of Book Selection in Eighteenth-Century Britain. Eighteenth-Century Studies 33: 43-64.

Krajewski, Markus. 2012. Die Bibliothek als Meta-Medium. In Handbuch Bibliothek: Geschichte, Aufgaben, Perspektiven, ed. Konrad Umlauf and Stefan Gradmann, 81-89. Stuttgart: Metzler. https://doi. org/10.1007/978-3-476-05185-1.

Mainberger, Sabine. 2003. Die Kunst des Aufzäblens: Elemente zu einer Poetik des Enumerativen. Berlin: De Gruyter.

Rösch, Hermann. 2012. Die Bibliothek und ihre Dienstleistungen. In Handbuch Bibliothek: Geschichte, Aufgaben, Perspektiven, ed. Konrad Umlauf and Stefan Gradmann, 89-100. Stuttgart: Metzler. https://doi. org/10.1007/978-3-476-05185-1.

Shadwell, Thomas. 1966. The Virtuoso. Eds. Marjorie H. Nicolson and David S. Rodes. Lincoln: University of Nebraska Press.

Smeed, John William. 1985. The Theophrastan 'Character': The History of a Literary Genre. Oxford: Clarendon.

Stagl, Justin. 1998. Homo Collector: Zur Anthropologie und Soziologie des Sammelns. In Sammler-Bibliophile-Exzentriker, ed. Aleida Assmann, Monika Gomille, and Gabriele Rippl, 37-54. Tübingen: Gunther Narr Verlag.

Vedder, Ulrike. 2011. Das Testament als literarisches Dispositiv: Kulturelle Praktiken des Erbes in der Literatur des 19. Jabrhunderts. Munich: Fink. 
von Contzen, Eva. 2017a. Die Affordanzen der Liste. Zeitschrift für Literaturwissenschaft und Linguistik 47: 317-326.

— 2017b. Grenzfälle des Erzählens: Die Liste als einfache Form. In Komplexität und Einfachbeit, ed. Albrecht Koschorke, 221-239. Stuttgart: Metzler. Springer Nature. https://doi.org/10.1007/978-3-476-04357-3_13. Williams, Abigail. 2017. The Social Life of Books: Reading Together in the EighteenthCentury Home. New Haven: Yale University Press. https://doi. org/10.12987/9780300228106.

Open Access This chapter is licensed under the terms of the Creative Commons Attribution 4.0 International License (http://creativecommons.org/licenses/ by $/ 4.0 /$ ), which permits use, sharing, adaptation, distribution and reproduction in any medium or format, as long as you give appropriate credit to the original author(s) and the source, provide a link to the Creative Commons licence and indicate if changes were made.

The images or other third party material in this chapter are included in the chapter's Creative Commons licence, unless indicated otherwise in a credit line to the material. If material is not included in the chapter's Creative Commons licence and your intended use is not permitted by statutory regulation or exceeds the permitted use, you will need to obtain permission directly from the copyright holder.

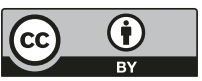

